\title{
Energy Values and Technologies for Non woody Biomass: as a clean source of Energy
}

\author{
Sonia Grover ${ }^{1}$, Rupinderjit Singh Kathuria ${ }^{2}$, Maninder Kaur ${ }^{3}$ \\ ${ }^{I}$ Department of Electrical Engineering \\ Guru Nanak dev Engineering College Ludhiana, Punjab, India \\ ${ }^{2}$ Department of Electrical Engineering \\ Guru Nanak dev Engineering College Ludhiana, Punjab, India \\ ${ }^{3}$ Department of Electrical Engineering \\ Guru Nanak dev Engineering College Ludhiana, Punjab, India
}

\begin{abstract}
Energy is the basic requirement for a developing country like India. Due to continuous development the energy demand is increasing more tremendously than the increase in population. To meet this energy demand the fossil fuels reserves are continuously depleting. The fossil fuels like coal, petroleum, gas etc. are used for power generation. Any other solution for power generation is required to save reserves and environment. The renewable energy sources are the best solution for this problem.

This paper reveals the main renewable energy for power generation and its availability in different states of Punjab. We discuss the various technologies that can be used to use dry or wet biomass for power generation. In view of high energy potential in agricultural potential, proximate analysis, gross calorific value and ultimate analysis is done for different crop samples collected from Punjab state.
\end{abstract}

Keywords - Biomass, Potential, Power, Renewable Energy, Technologies.

\section{Introduction}

The overall energy demand of world is increasing at faster rate than the increase in population. The overall generation in the country has increased from 771.551 during 2009-10 to 811.143 during the year 201011. [1] To meet the increasing demand renewable energy sources are the best method for power generation. Many areas of our country are still without any access to any form of electricity. Electrification of these areas can be done by distributed generation using renewable energy sources. Renewable form of energy mean a lot for India due to two reasons, Firstly, it is available in abundance, secondly it enhance energy security and reduce environmental impacts. The main renewable sources available in our country are biomass, solar, wind and hydro power. As hydro power generation is possible only if the area has plenty of water, wind energy is usually restricted to coastal areas and solar energy has high initial capital investment cost. So theserenewable energy sources are restricted to particular region. As in India most of the people has agriculture as their occupation, the agri-waste residue is the major source for power generation. Biomass available in plenty in most of the parts of India can be utilized for energy generation. The total biomass available in India with energy potential estimation is shown in the Table 1.1

TABLE 1.1- Total Potential Estimation of Biomass

\begin{tabular}{|l|l|l|}
\hline S. No. & Item & $\begin{array}{l}\text { Estimated } \\
\text { Potential }\end{array}$ \\
\hline 1 & $\begin{array}{l}\text { Bio-power (Agri-residue } \\
\text { and Plantation) }\end{array}$ & $16881 \mathrm{MW}$ \\
\hline 2 & Co-generation (Bagasse) & $5000 \mathrm{MW}$ \\
\hline 3 & $\begin{array}{l}\text { Waste to Energy (Urban } \\
\text { and Industrial) }\end{array}$ & $2700 \mathrm{MW}$ \\
\hline 4 & Total & $24581 \mathrm{MW}$ \\
\hline
\end{tabular}

Source: MNRE website

Renewable sources of energy have attracted global attention and evoked interest among planners, policy makers, economists and environmental activists as a viable option to achieve the goal of sustainable development. If the current interest in renewable source of energy gets concretized into projects to tap their enormous potential, the energy generation in $21^{\text {st }}$ century can be expected to move away from fossil fuel. 
In view of high energy potential in agricultural waste an attempt has been made to calculate the proximate analysis and energy content $(\mathrm{GCV})$ of different types of biomass, so that proper utilization can be made for power generation using agricultural waste.

\section{Biomass And Bioenergy}

Biomass is an organic matter and the energy released from biomass when it is burnt is called biomass energy. In India biomass is predominate for generation due to its properties like: renewable, widely available and carbon neutral.

Biomass contains stored energy from Sun. Plants absorbs $\mathrm{CO}_{2}$ from the atmosphere while photosynthesis and releases the same $\mathrm{CO}_{2}$ while burning. Biomass has one more advantage that it can be used for power generation with the same equipments which are used for fossil fuel generation. Biomass used as energy feedstock is environment friendly because biomass recycles the carbon in the environment and does not add $\mathrm{CO}_{2}$ in atmosphere. [4]

Biomass basically is classified in two categories: woody and non woody. Woody biomass consist of high bulk density, less void age, low ash content, low moisture content, high calorific value like forest based residue and agro industrial residue. Non woody biomass characterized as lower bulk density, higher void age, higher ash content, higher moisture content and lower calorific value like agriculture residue, animal waste, urban and industrial solid waste.

\section{Biomass Availability}

Different types of biomass are available in different areas. The northern states of Punjab and Haryana are rich due to multi cropping practices. The main biomass is wheat and rice straw. Some amount of cotton stalks is also available in the western part of Punjab. Agro industrial residue like rice husk, sugarcane bagasse, ground nut and soya shells are also available in commercial market and almost the entire quantity of generated waste is efficiently used. In Rajasthan main source of biomass is mustard residue. In Maharashtra cotton stalks are available in large amount and Madhya Pradesh has soya residue.

\section{Technologies For Bio-Power}

Biomass power can be generated by using two technologies one is thermo-chemical and other is biochemical. In thermo-chemical: direct firing, co-firing, gasification and pyrolysis techniques can be used for woody biomass, while in bio-chemical anaerobic digestion and fermentation techniques can be used for non woody biomass. [2]

\subsection{Direct combustion}

Direct combustion is similar to thermal power generation, in which biomass is burnt in the boiler and produce steam to run the turbine to produce electricity. It is based on rankine steam cycle. The chemical reaction is:

$$
\mathrm{C}_{\mathrm{x}} \mathrm{H}_{\mathrm{y}} \mathrm{O}+\mathrm{O}_{2} \longrightarrow \mathrm{CO}_{2}+\mathrm{H}_{2} \mathrm{O}+\mathrm{Heat}
$$

The capacity range of these plants is ranges from $0.5 \mathrm{MW}$ to $10 \mathrm{MW}$ and the efficiency range of these plants are $15-25 \%$.

This technology disposes of large amount of residue and wastes. The block diagram of direct firing is shown in Fig. 4.1.

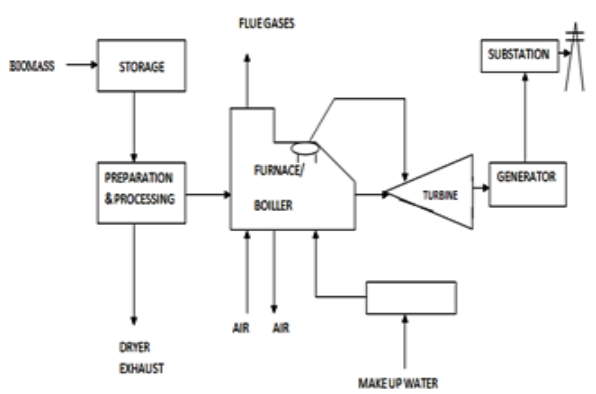

Figure 4.1 block diagram of direct firing

\subsection{Co-firing}

Co-firing is mixing of a percentage of biomass with the coal in coal fired stations. Co-firing can also be used to improve the combustion of fuels with low energy content. The different options for co-firing:-

4.2.1 Biomass blending with coal or Direct firing - It is simple and least cost approach. Biomass fuels are blended with coal and blend is sent to the firing system.

4.2.2 Separate Injection or Indirect firing - In this approach the biomass is separately injected into the boiler without impacting the coal delivery process. This method involves more equipment than the first approach.

$$
\text { wWw.iosrjournals.org }
$$


4.2.3 Gasification based Co-firing - In this approach, biomass is first fed to gasifier to generate producer gas and then it is fired in boiler.

\subsection{Gasification}

Gasification is a technique in which thermo chemical conversion of solid biomass into highly combustible gas for burning is obtained by partial oxidation under high temperature. [3] The gas obtained from the gasification process is a mixture of $\mathrm{CO}, \mathrm{H}_{2}$ and $\mathrm{CH}_{4}$ with $\mathrm{CO}_{2}$ andN $\mathrm{N}_{2}$. The gas can be used in internal combustion engine or in gas turbine.

\subsection{Pyrolysis}

Pyrolysis is biomass conversion technique, through which biomass is converted to liquid, solid and gaseous fractions by heating the biomass in the absence of air or oxygen. In this volatile component of the waste are vaporized by heating, leaving residue consist of char and ash.

\subsection{Anaerobic Digestion}

In anaerobic digestion, organic material is broken down by bacteria in the absence of oxygen, to produce methane rich biogas. The solid waste left can be used as compost in fields. There are four biological and chemical stages of anaerobic digestion shown in Fig 4.2.

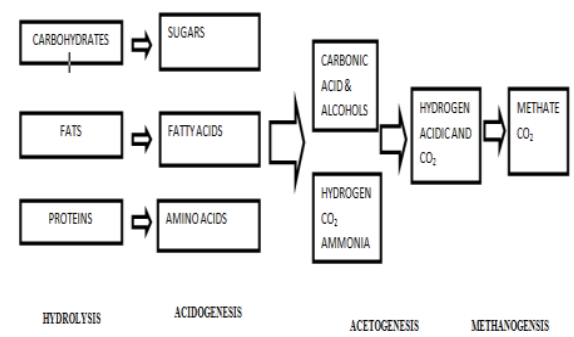

\subsection{Fermentation}

Figure 4.2 four stages of anaerobic digestion

Fermentation is a technique in which a mixture of $60 \%$ methane and $40 \% \mathrm{CO}_{2}$ produced through anaerobic fermentation of material like plants vegetable waste and animal waste etc. This method requires large installation cost, longer reaction time, high amount of water and large area for installation of plant. Production of ethanol and methanol:

4.6.1 Ethanol - Ethanol is produced from the biomass like sugarcane, starches and cellulose i.e. wood and agricultural residues

4.6.2 Methanol - High cellulose content materials such as wood and agricultural residues are suitable for methanol production.

\section{Proximate and Ultimate Analysis}

In this paper proximate and ultimate analysis of some of the samples of biomass is carried out. For this study only crop residue generated by agricultural productions is considered. The crop residue selected for analysis are rice straw, wheat straw, cotton stalk, mustard straw, mungi and groundnut straw etc.

Proximate analysis gives the fixed carbon, volatile matter, moisture and ash content of biomass and gross calorific value or higher calorific value is the heat liberated by the combustion of one $\mathrm{Kg}$ of fuel at $0^{\circ} \mathrm{C}$ and under $760 \mathrm{~mm}$ of mercury. GCV is measures with the aid of the Mahler bomb calorimeter. The Table 1.2 shows the results of proximate analysis and gross calorific value of different crop samples.

Ultimate analysis gives the composition of the biomass in weight $\%$ of carbon, hydrogen, oxygen, as well as sulphur and nitrogen. The results of ultimate analysis is shown in Table 1.3 
Energy Values and Technologies for Non woody Biomass: as a clean source of Energy

Table 5.1 proximate analysis of different samples

\begin{tabular}{|c|c|c|c|c|c|c|c|}
\hline \multirow[b]{2}{*}{$\begin{array}{l}\text { S. } \\
\text { No. }\end{array}$} & \multirow[b]{2}{*}{ Commodity } & \multicolumn{4}{|c|}{ Proximate analysis } & \multirow[b]{2}{*}{$\begin{array}{l}\text { GCV } \\
\text { kcal/kg }\end{array}$} & \multirow[b]{2}{*}{$\begin{array}{l}\text { Bulk } \\
\text { Density } \\
\mathrm{Kg} / \mathrm{m}^{3}\end{array}$} \\
\hline & & $\begin{array}{l}\text { Moisture } \\
\%\end{array}$ & $\begin{array}{l}\text { Ash } \\
\%\end{array}$ & $\begin{array}{l}\text { Volatile } \\
\text { Matter } \\
\%\end{array}$ & $\begin{array}{l}\text { Fixed } \\
\text { Carbon } \\
\% \\
\end{array}$ & & \\
\hline 1 & $\begin{array}{l}\text { Wheat } \\
\text { Straw }\end{array}$ & 4.99 & 7.58 & 71.41 & 16.02 & 4010 & 47 \\
\hline 2 & $\begin{array}{l}\text { Mustard } \\
\text { Straw }\end{array}$ & 7.64 & 6.34 & 68.36 & 17.66 & 4074 & 94 \\
\hline 3 & Rice Wapsi & 4.58 & 17.39 & 60.82 & 17.21 & 3429 & 192 \\
\hline 4 & $\begin{array}{l}\text { Channa } \\
\text { Straw }\end{array}$ & 6.19 & 8.01 & 70.59 & 15.21 & 3726 & 262 \\
\hline 5 & Leaves & 5.76 & 7.15 & 67.17 & 19.92 & 4625 & 254 \\
\hline 6 & Chip Cotton & 6.74 & 4.55 & 67.73 & 20.98 & 4580 & 155 \\
\hline 7 & $\begin{array}{l}\text { Mungi } \\
\text { Straw }\end{array}$ & 6.8 & 11.58 & 66.33 & 15.29 & 3782 & 272 \\
\hline 8 & $\begin{array}{l}\text { Mungfali } \\
\text { Straw }\end{array}$ & 5.89 & 16.32 & 61.41 & 16.38 & 3949 & 171 \\
\hline 9 & $\begin{array}{l}\text { Paddy } \\
\text { Straw }\end{array}$ & 4.3 & 20.49 & 61.2 & 14.01 & 3309 & 142 \\
\hline
\end{tabular}

Table 5.2 ultimate analysis of different samples

\begin{tabular}{|l|l|l|l|l|l|l|}
\hline \multirow{2}{*}{$\begin{array}{c}\text { S. } \\
\text { No. }\end{array}$} & Commodity & \multicolumn{6}{|c|}{ Ultimate analysis } \\
\cline { 3 - 7 } & $\mathrm{C} \%$ & $\begin{array}{l}\mathrm{H} \\
\%\end{array}$ & $\begin{array}{l}\mathrm{N} \\
\%\end{array}$ & $\mathrm{~S} \%$ & $\mathrm{O} \%$ \\
\hline 1 & $\begin{array}{l}\text { Wheat } \\
\text { Straw }\end{array}$ & 46.46 & 5.12 & 0.47 & 0.18 & 35.2 \\
\hline 2 & $\begin{array}{l}\text { Mustard } \\
\text { Straw }\end{array}$ & 46.48 & 5.08 & 0.74 & 0.36 & 33.36 \\
\hline 3 & Rice Wapsi & 45.4 & 4.18 & 0.87 & 0.14 & 31.44 \\
\hline 4 & $\begin{array}{l}\text { Channa } \\
\text { Straw }\end{array}$ & 44.6 & 4.79 & 0.77 & 0.1 & 35.54 \\
\hline 5 & Leaves & 52.42 & 4.72 & 1.1 & 0.17 & 28.68 \\
\hline 6 & $\begin{array}{l}\text { Chip } \\
\text { Cotton }\end{array}$ & 48.91 & 4.9 & 1.09 & 0.16 & 33.65 \\
\hline 7 & $\begin{array}{l}\text { Mungi } \\
\text { Straw }\end{array}$ & 44.62 & 4.36 & 1.6 & 0.38 & 30.66 \\
\hline 8 & $\begin{array}{l}\text { Mungfali } \\
\text { Straw }\end{array}$ & 46.02 & 3.98 & 1.2 & 0.26 & 26.33 \\
\hline 9 & $\begin{array}{l}\text { Paddy } \\
\text { Straw }\end{array}$ & 39.99 & 3.97 & 0.79 & 0.2 & 30.26 \\
\hline
\end{tabular}

\section{Conclusion}

From all the technologies it is concluded that there are mainly two types of biomass conversion technique: thermo-chemical and bio-chemical conversion. Thermo-chemical conversion techniques are direct firing, co-firing, gasification and pyrolysis. Anaerobic digestion and fermentation are bio-chemical conversion techniques. Biomass to electricity conversion techniques are used in many parts of the world for small to medium scale decentralized or grid connected plants of number of sizes. The values for moisture content, ash content, fixed carbon and GCV are calculated and shown in table 5.1. The value of percentage of composition of different components is shown in table 5.2. We can conclude that biomass has the same potential to generate electricity, so we have to use it for generation purpose, as it is a clean source of energy. 


\section{REFERENCES}

[1] Ministry of power, government of India, available: http://www.powermin.nic.in

[2] Mathias Loeser and Miles Alexander Redfern, Overview of Biomass Conversion and Generation Technologies, International Universities Power Engineering Conference, Padova, Italy, Sept 2008, 1-4.

[3] Shouyu Zhang, Dingmao Peng and Fengbao Huang, Effect of Mineral Matter on the Reactivity of the Char from Agricultural Waste, International Conference on Energy and Environment Technology, 2009, 286-289.

[4] S. Murali, Rajnish Shrivastava, Mohini Saxena, Quantification of agricultural residues for energy generation -A Case Study Journal of the IPHE 3, India, 2007-08.

[5] Richard L .Bain, An Overview of Biomass Combined Heat and Power Technologies, Power Engineering Society General Meeting, IEEE, Denver, CO, 2004, 1657 - 1659

[6] Amit Jain, Sustainable Energy Plan for an Indian Village International Conference on Power System Technology, Hangzhou, 2010, 1-8

[7] Ravindranath N.H. and Balachandra P., Sustainable bioenergy for India technical, economic and policy analysis, Energy 34, 2009, 1003-1013.[8] M. Kumar and S. K. Patel, Energy Values and Estimation of Power Generation Potentials of Some Nonwoody Biomass Species, Energy Sources, Part A: Recovery, Utilization and Environmental Effects 30(8), 2008,765 - 773.

[9] I. R. Pillai, and R. Banerjee, Renewable energy in India: Status and potential, Energy 34, 2009, 970-980.

[10] N.H. Ravindranath, P. Balachandra, S. Dasappa and Usha K. Rao, Bioenergy technologies for carbon abatement, Biomass and Bioenergy 30, 2006 826-837. 